Article

\title{
Effect of Tidal Cycling Rate on the Distribution and Abundance of Nitrogen-Oxidizing Bacteria in a Bench-Scale Fill-and-Drain Bioreactor
}

\author{
Joseph M. Battistelli ${ }^{1,2}$ (D), Rima B. Franklin ${ }^{2, *}$ and Aaron L. Mills ${ }^{1}$ \\ 1 Department of Environmental Sciences, University of Virginia, Charlottesville, VA 22904, USA; \\ battistellij@vcu.edu (J.M.B.); amills@virginia.edu (A.L.M.) \\ 2 Department of Biology, Virginia Commonwealth University, Richmond, VA 23284, USA \\ * Correspondence: rbfranklin@vcu.edu; Tel.: +1-804-828-6753
}

Received: 7 March 2018; Accepted: 11 April 2018; Published: 17 April 2018

\begin{abstract}
Most domestic wastewater can be effectively treated for secondary uses by engineered biological systems. These systems rely on microbial activity to reduce nitrogen $(\mathrm{N})$ content of the reclaimed water. Such systems often employ a tidal-flow process to minimize space requirements for the coupling of aerobic and anaerobic metabolic processes. In this study, laboratory-scale tidal-flow treatment systems were studied to determine how the frequency and duration of tidal cycling may impact reactor performance. Fluorescent in situ hybridization and epifluorescence microscopy were used to enumerate the key functional groups of bacteria responsible for nitrification and anaerobic ammonium oxidation (anammox), and N-removal efficiency was calculated via a mass-balance approach. When water was cycled (i.e., reactors were filled and drained) at high frequencies (16-24 cycles day ${ }^{-1}$ ), nitrate accumulated in the columns-presumably due to inadequate periods of anoxia that limited denitrification. At lower frequencies, such as 4 cycles day $^{-1}$, nearly complete $\mathrm{N}$ removal was achieved (80-90\%). These fill-and-drain systems enriched heavily for nitrifiers, with relatively few anammox-capable organisms. The microbial community produced was robust, surviving well through short (up to $3 \mathrm{~h}$ ) anaerobic periods and frequent system-wide perturbation.
\end{abstract}

Keywords: ammonium oxidizing bacteria; nitrite oxidizing bacteria; anammox; wastewater treatment; fill and drain; constructed wetlands; nitrification; bioreactors

\section{Introduction}

Despite vast quantities of water on earth, a mere 3\% is suitable for human consumption [1]. As populations grow, the need for potable water will continue to increase, and water re-use is key to meeting this demand. Treating wastewater to (re)generate potable water is costly compared to treating water only for secondary uses (e.g., flush water, cooling tower water, or use in a water feature). One promising approach to address the growing water crisis is to develop more efficient and affordable on-site means of treating water for secondary uses in hopes of reducing unnecessary demand on the potable water supply. A key consideration when treating water for secondary uses is removal of reactive nitrogen $(\mathrm{N})$. Nitrogen is a major component of most wastewater, and excess $\mathrm{N}$ has a negative effect on both human and environmental health [2,3]. Though there are physiochemical treatments for removing $\mathrm{N}$, biological systems that rely on microbial processes are more efficient, reliable, and effective [4-6]. These systems depend on the synergistic relationships among several different functional groups of microorganisms to convert reactive $\mathrm{N}$ to inert $\mathrm{N}_{2}$ gas. 
The predominant form of reactive $\mathrm{N}$ found in wastewater is ammonium $\left(\mathrm{NH}_{4}{ }^{+}\right)$, which can be oxidized by both aerobic and anaerobic species of bacteria and archaea. The most commonly studied processes are aerobic nitrification, wherein ammonium oxidizing bacteria (AOB) and archaea (AOA) convert $\mathrm{NH}_{4}{ }^{+}$to nitrite $\left(\mathrm{NO}_{2}{ }^{-}\right)$, which is then further oxidized to nitrate $\left(\mathrm{NO}_{3}{ }^{-}\right)$by nitrite oxidizing bacteria (NOB). Thus far, AOA have been found primarily in sediment and soil communities [7] and their contribution to $\mathrm{N}$ processing in wastewater systems is generally thought to be small, particularly in systems treating more concentrated influent [8]. In most wastewater-processing systems, aerobic nitrification is followed by anaerobic denitrification, in which organic matter is mineralized using $\mathrm{NO}_{3}{ }^{-}$as the terminal electron acceptor to yield $\mathrm{N}_{2}$, effectively removing reactive $\mathrm{N}$ from the system. As nitrification is aerobic, while denitrification is predominantly anaerobic, these processes are usually conducted in separate reactors. An alternate pathway for $\mathrm{N}$ removal is anaerobic ammonium oxidation (anammox), which oxidizes $\mathrm{NH}_{4}{ }^{+}$using $\mathrm{NO}_{2}{ }^{-}$to produce $\mathrm{N}_{2}$. Anammox bacteria (AXB) are often considered desirable for wastewater treatment because they produce thin biofilms that are less prone to "sloughing" (the shedding of cellular aggregates) compared to heterotrophic denitrifying biofilms, thus requiring less maintenance effort $[9,10]$. Additionally, the use of anammox could also help mitigate $\mathrm{N}_{2} \mathrm{O}$ emissions because, unlike denitrification, anammox does not produce $\mathrm{N}_{2} \mathrm{O}$ as a byproduct [11].

Constructed wetlands are commonly used for on-site treatment of wastewater. They are generally quite efficient at removing organic matter and pollutants such as metals, but their architecture limits $\mathrm{N}$ removal. In particular, horizontal wetlands tend to develop anoxic conditions with little opportunity for aerobic nitrification to occur $[12,13]$. Vertical wetlands attempt to remedy the oxygen $\left(\mathrm{O}_{2}\right)$ limitation, but often result in an inadequate anaerobic phase for denitrification [14,15]. In addition, both types of treatment wetlands require extensive energy inputs and space [16], and neither are easily adapted to allow water reclamation. An alternate approach to on-site wastewater treatment in a constructed wetland is the "tidal fill-and-drain treatment system" [17]. This system cycles by repeatedly filling and draining the treatment beds, which allows temporal juxtaposition of aerobic and anaerobic phases within the same bed-allowing for enrichment of AOB and NOB along with AXB and denitrifiers, respectively - while maintaining a small spatial and ecological footprint. The performance of these reactors can be enhanced by using a support medium that has a high cation exchange capacity, which will help retain $\mathrm{NH}_{4}{ }^{+}$when the reactor is drained. This increases $\mathrm{NH}_{4}{ }^{+}$availability during the aerobic phases and enhances nitrification in these types of systems [18].

Recent studies of laboratory-scale fill-and-drain systems have demonstrated their potential to remove $\mathrm{N}$ [19], but it is unclear if this is all due to coupled nitrification-denitrification reactions or if there is a substantive contribution from anammox. One key goal of the research described here is to evaluate the relative importance of these two pathways by monitoring the distribution and abundance of $\mathrm{N}$ oxidizing bacteria, specifically $\mathrm{AOB}, \mathrm{NOB}$, and $\mathrm{AXB}$, in the biofilms of laboratory-scale tidal wastewater-treatment systems. These groups are direct competitors for $\mathrm{NH}_{4}{ }^{+}$(the energy source for $\mathrm{AOB}$ and $\mathrm{AXB}$ ) and $\mathrm{NO}_{2}{ }^{-}$(energy source for $\mathrm{NOB}$ and terminal electron acceptor for $\mathrm{AXB}$ ), and their activity dictates the potential of the reactor for overall $\mathrm{N}$ removal. Since these microbial groups vary in their need for, and tolerance of, $\mathrm{O}_{2}$, one key challenge in designing this sort of wastewater reactor is determining the best cycling frequency to maintain a stable community of aerobic microorganisms (AOB and NOB) alongside a community of anaerobes (either AXB or denitrifiers). In the work described here, we specifically tested the effect of cycling frequency (i.e., the duration of "filled" vs. "drained" phases) on the survival and function of these microbial groups in an effort to determine optimum reactor conditions for maximum $\mathrm{N}$ removal. These tests were conducted using wastewater with varying $\mathrm{N}$ loads, and $\mathrm{N}$ removal efficiency was calculated based on changes in the concentration of dissolved inorganic $\mathrm{N}$. Abundance of microbial functional groups was determined using fluorescent in situ hybridization (FISH) with epifluorescence microscopy. 


\section{Materials and Methods}

\subsection{Reactor Design}

Two column reactors were constructed from polyvinyl chloride (PVC) pipe $(9.8 \mathrm{~cm}$ diameter $\times 1.1 \mathrm{~m}$ height, yielding an effective working volume of $8.3 \mathrm{~L}$ ). Each column was loosely packed with lightweight expanded shale aggregate (LESA; Utelite Corp., Coalville, UT, USA). LESA is produced by heating shale aggregates to very high temperatures $\left(>1000^{\circ} \mathrm{C}\right)$, which causes the sedimentary layers to expand, yielding a porous, highly fractured, light-weight pebble that is similar in appearance to crushed brick. The characteristics of LESA are described more fully in Austin [18]. The material is an ideal fill for bioreactors because it has: (i) considerable surface area for microbial biofilm growth; and (ii) a high cation exchange capacity $\left(1.2 \mathrm{meq} 100 \mathrm{~g}^{-1} \mathrm{LESA}\right.$, as determined by EPA Method 9081) [18,20]. The specific gravity of the LESA we used was 1.56 , the density was $770 \mathrm{~kg} \mathrm{~m}^{-3}$, and the average stone size was $9.5 \mathrm{~mm}$. To determine the surface area of the LESA pebbles, we expanded the approach of Tokunaga et al. [21], who used a power function to calculate surface area of similarly sized gravel particles, in order to account for inner porosity. Using the mass of the water film (determined by comparing the wet and dry weights of LESA), we calculated the average surface area of each stone to be $4.3 \mathrm{~cm}^{2}$, which corresponds to a total surface area of $35 \mathrm{~m}^{2}$ in each reactor $\left(\sim 4200 \mathrm{~m}^{2} \mathrm{~m}^{-3}\right)$. The columns had sampling ports along their length at $\sim 20 \mathrm{~cm}$ increments (Figure 1). Each reactor was fitted with a multidirectional valve that allowed flow to and from a 7-L reservoir at the base of the column. The operation of each reactor was controlled by a Siemens TD-200 Programmable Logic Controller (Siemens, Johnson City, TN, USA).

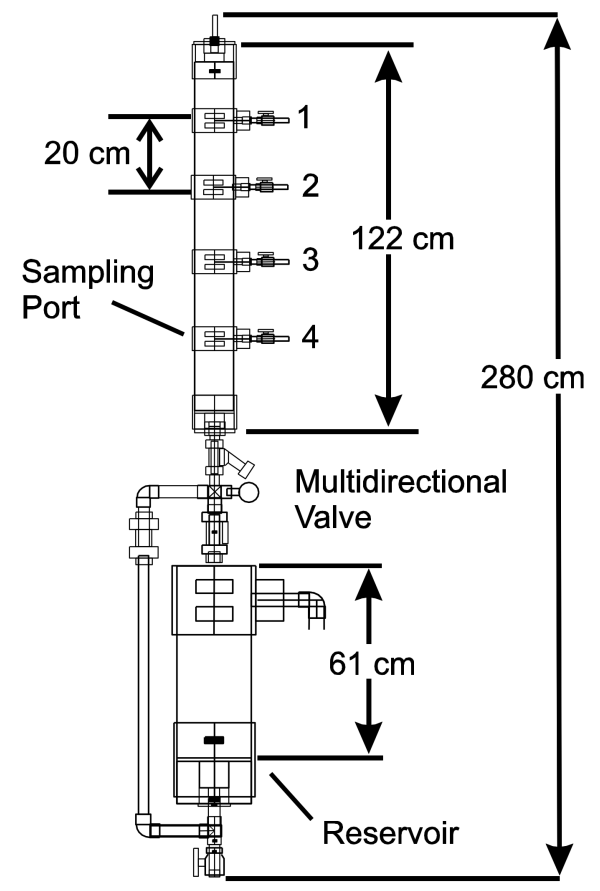

Figure 1. Schematic of the column reactors used in this study.

\subsection{Experiments}

Two parameters were manipulated in this study: $\mathrm{N}$ load (high vs. low) and cycling frequency $(24,16,8$, and 4 fill-and-drain events per day). Unfortunately, because of the relatively large size of these reactors and the considerable infrastructure necessary to control flow, it was not feasible to maintain multiple reactors of each $\mathrm{N} \times$ cycling-frequency combination. Instead, we designated one reactor "High N" and the second "Low N" and performed the cycling experiments sequentially (details 
below). The "High $\mathrm{N}^{\text {" reactor received a synthetic waste-stream load of } 3.7 \mathrm{~g} \text { day }}{ }^{-1}$ of urea (equivalent to $2.3 \mathrm{~g}$ day $^{-1}$ of $\left.\mathrm{NH}_{4}{ }^{+}-\mathrm{N}\right)$, while the "Low $\mathrm{N}^{\prime}$ reactor received only $0.9 \mathrm{~g}_{\text {day }}{ }^{-1}$ of urea $\left(0.5 \mathrm{~g}\right.$ day $^{-1}$ of $\mathrm{NH}_{4}{ }^{+}-\mathrm{N}$ ). Each reactor received a daily dose of $\mathrm{NaHCO}_{3}$ (High N: $8.9 \mathrm{~g}$, Low N: $2.2 \mathrm{~g}$ ) to buffer the $\mathrm{H}^{+}$generated from nitrification. In addition, both reactors received $1.5 \mathrm{~g}^{-1 a y}{ }^{-1}$ of whey protein, which corresponds to a chemical oxygen demand (COD) of $1700 \mathrm{mg} \mathrm{COD} \mathrm{L}^{-1}$. The COD loading rate was selected as an intermediate value between municipal waste stream (e.g., 0.19-0.34 mg COD L $\mathrm{m}^{-1}$ as reported by Abou-Elela and Hellal [22]) and piggery waste (e.g., 20-50 g COD L ${ }^{-1}$ as reported by Boursier et al. [23]). Piggeries frequently utilize treatment wetlands for $\mathrm{N}$ removal, and thus represent a reasonable point-of-use end member.

Reactors were initially inoculated with a mixture of activated sludge from a nearby municipal wastewater treatment plant and pond scum from a small stagnant retention basin. They were then allowed to run for about 6 months alternating 30-min-filled and 30-min-drained phases (note that the transition time between "full" and "drained" was less than $2 \mathrm{~min}$ and consistent across all cycling treatments). After this equilibration period, the following four cycling treatments were studied: (i) 24 cycles per day (resulting in 30-min-filled and 30-min-drained phases); (ii) 16 cycles (45 min phases); (iii) 8 cycles (90 min); and (iv) 4 cycles (180 min), with a 4 week "reset" period associated with each change. For example, after the samples for the " 24 cycles per day" treatment were collected, cycling was changed to 16 per day and allowed to equilibrate for 4 weeks prior to collecting the "16 per day" microbial samples. The reset period of 4 weeks was chosen based on preliminary studies described in Battistelli [24], which demonstrated that this amount of time was adequate for effluent water chemistry (specifically $\mathrm{NH}_{4}{ }^{+}, \mathrm{NO}_{2}{ }^{-}$, and $\mathrm{NO}_{3}{ }^{-}$concentrations) to stabilize following disturbances associated with both increases (e.g., 4 cycles to 24 cycles) and decreases (24 to 16) in cycling frequency.

\subsection{Microbiological Sampling and Analysis}

At the end of each 4-week cycling treatment, the reactors were drained and triplicate samples of LESA ( $\sim 3 \mathrm{~g}$ each) were collected from each sampling port using sterile metal tubular spatulas. The reactor remained intact during sampling and special care was taken to minimize disturbance. The amount of LESA removed at each sampling event was less than $0.1 \%$ of the total reactor mass. Sampling only took place during times when the reactor was drained so as to avoid introducing $\mathrm{O}_{2}$ during anaerobic (filled) phases.

Samples were immediately processed to break apart the biofilms and dislodge bacterial cells from the LESA in preparation for staining and microscopy. First, a portion $(1 \mathrm{~g})$ of each sample was transferred to a sterile $15-\mathrm{mL}$ centrifuge tube with $3 \mathrm{~mL}$ of filter-sterilized phosphate-buffer saline (PBS) at $\mathrm{pH}=7.2$ (as prepared in Wright [25]). These tubes were then placed horizontally on a vortex mixer and agitated vigorously for $10 \mathrm{~min}$. An aliquot $(1 \mathrm{~mL})$ of the fluid was then transferred to a sterile $2-\mathrm{mL}$ centrifuge tube and centrifuged $(10,000 \times g, 10 \mathrm{~min})$. Next, liquid was decanted and the resultant cell pellet was re-suspended in $2 \mathrm{~mL}$ of a methanol PBS solution (1:1 by volume), incubated for $24 \mathrm{~h}$ at $4{ }^{\circ} \mathrm{C}$, and centrifuged again $(10,000 \times g, 10 \mathrm{~min})$. The supernatant was removed and this final cell pellet was re-suspended in $1 \mathrm{~mL}$ of ethanol-PBS solution (1:1 by volume) and stored at $-20^{\circ} \mathrm{C}$ until cells were enumerated by fluorescent in situ hybridization (FISH) as per Higgins [26]. The total abundance of (eu)bacteria, as well as the abundances of AOB and NOB, were determined using the Nitri-VIT kit (Vermicon, Munich, Germany) similar to the work of Krasnits et al. [27] and Woznica et al. [28]. Sample processing followed the manufacture's protocol with only the following modifications: (i) instead of using the slides provided in the kit, we used slides printed with hydrophobic wells (5-mm diameter wells, Coated Hydro Slides, Catalog \#ER202W, Thermo Scientific, Pittsburgh, PA, USA) as this allowed multiple samples to be processed on a single slide; (ii) archived (methanol-preserved) samples were re-suspended prior to analysis by gentle horizontal agitation on a vortex mixer (10 $\mathrm{min})$; (iii) after re-suspension and (when appropriate) dilution, $5 \mu \mathrm{L}$ of each sample was applied to a slide well and allowed to dry at $35^{\circ} \mathrm{C}$ for $10 \mathrm{~min}$ prior 
to hybridization; and (iv) reagent volumes were decreased by $60 \%$ to account for the smaller area of the wells compared to the Nitri-Vit slides.

Anammox bacteria were visualized using the probe S-*-Amx-0368-a-A-18 (Amx368) [29], which targets the broadest range of anammox-capable bacteria, in conjunction with the Planctomycetes probe S-P-Planc-0046-a-A-18 (Pla046) [30], to confirm correct hybridization. Probe Amx368 was labeled with FAM, a fluorescein-based dye that fluoresces green, and probe Pla046 was labeled with Cy3, a cyanine-based dye that fluoresces orange (Integrated DNA Technologies, Coralville, IA, USA). Hybridizations were conducted in series beginning with Pla046 probe according to Neef et al. [30] and Schmid et al. [29]. Only cells that contained both probes were counted as AXB.

Enumeration was done by manual counting (10 fields) using either a Zeiss Axioscope (Zeiss Microscopy, Thornwood, NY, USA) or an Olympus BX41 epifluorescence microscope (Olympus Corporation, Center Valley, PA, USA) at 1000 $\times$ magnification, fitted with filter sets for Cy3 and FAM. Counts were converted to cells per gram LESA based on Brandsma et al. [31] and $\log _{(10)}$ transformed prior to statistical analyses.

To compare the distribution of each microbial group across depth in each column, analysis of variance (ANOVA) was used ( $\mathrm{df}=11, \alpha=0.05$ ) followed by Tukey's post hoc tests. To compare across cycling treatments, total reactor abundance of each microbial group was calculated by integrating across depth, assuming that each sampling port was representative of one fourth of the reactor. Pearson correlation analyses were used to examine the relationships between the abundance of each microbial group.

\subsection{Water Sampling and Analysis}

Wastewater samples $(10 \mathrm{~mL})$ were collected weekly from the reservoir of each reactor to examine overall changes in dissolved inorganic $\mathrm{N}$ concentrations. In addition, samples were collected from each vertical sampling port co-incident with biofilm (LESA) sampling events. Liquid was immediately filtered through 0.2- $\mu \mathrm{m}$ pore-size polycarbonate filters (Pall Corporation, Port Washington, NY, USA) and frozen $\left(-20^{\circ} \mathrm{C}\right)$ for later analysis via ion chromatography to determine concentrations of $\mathrm{NH}_{4}{ }^{+}$, $\mathrm{NO}_{2}{ }^{-}$, and $\mathrm{NO}_{3}{ }^{-}$. We used an ICS-2100 Ion Chromatograph (Dionex, Pittsburgh, PA, USA) using an AS18 column with an ASRS $300(4 \mathrm{~mm})$ suppressor for anions and a CS12 column with a CSRS $300(4 \mathrm{~mm})$ suppressor for cations. We used $\mathrm{KOH}$ as the eluent, with an injection volume of $20 \mu \mathrm{L}$ and a flow rate of $1.0 \mathrm{~mL} \mathrm{~min}^{-1}$. Concentrations are reported throughout this paper as $\mathrm{mg}-\mathrm{N} \mathrm{L}^{-1}$. The lower limit of detection for all three ions was $0.1 \mathrm{mg} \mathrm{L}^{-1}$.

The chemistry of the wastewater samples collected from each sampling port consistently matched the chemistry of reservoir fluid; for simplicity, only reservoir data are presented here. Throughout the experiment, the concentration of $\mathrm{NO}_{2}{ }^{-}$was below detection $\left(<0.1 \mathrm{mg} \mathrm{L}^{-1}\right)$, so total $\mathrm{N}$ was calculated as the sum of $\mathrm{NH}_{4}{ }^{+}$and $\mathrm{NO}_{3}{ }^{-}$concentrations. Efficiency of $\mathrm{N}$ removal was determined using a mass balance approach. Specifically, measured concentration values were used to determine the total dissolved $\mathrm{N}$ within the reactor fluid, and this amount was subtracted from the $\mathrm{N}$ inputs to the reactor to calculate microbially-mediated $\mathrm{N}$ removal.

\section{Results}

\subsection{Bacterial Abundance}

The vertical distribution of abundance for each bacterial group under each set of cycling conditions was compared, and Figure 2 shows representative graphs for the fastest (24) and slowest (4) cycling rates. When the high-N reactor was operated at 24 cycles day $^{-1}$ (Figure 2a), a significant increase in abundance was observed with depth for total bacteria, AOB, and NOB (Table 1); a similar change in $\mathrm{AOB}$ and $\mathrm{NOB}$ was evident in the low-N reactor (Figure $2 b$ ). In contrast, depth had no effect on abundance for any of the functional groups when the reactors were cycled four times per day (Figure 2c,d). Similar results were obtained for the intermediate rates (16 and 8 cycles day $^{-1}$; data 
not shown, all ANOVA $p>0.23$ ). Across all depths and treatments, functional group abundance was highest for AOB. On average, this group represented 25\% (ranged from 11 to $47 \%$ ) of the total bacterial population. The proportion of the community that were NOB (average: 5\%; range: 1-10\%) or AXB (average: $0.1 \%$; range: $0.1-2 \%$ ) was always much lower.

(a) High N, 24 cycles

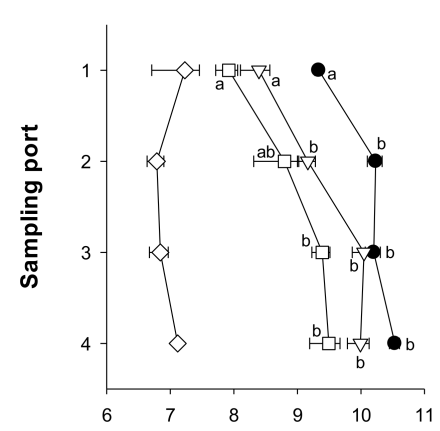

(c) High N, 4 cycles

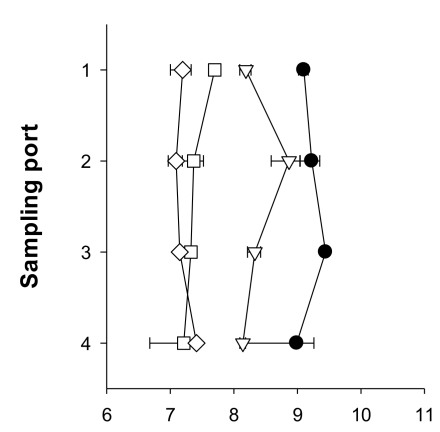

(b) Low N, 24 cycles

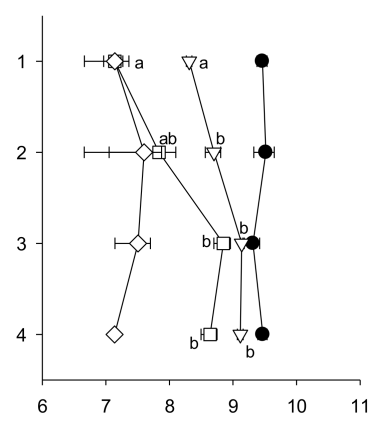

(d) Low N, 4 cycles

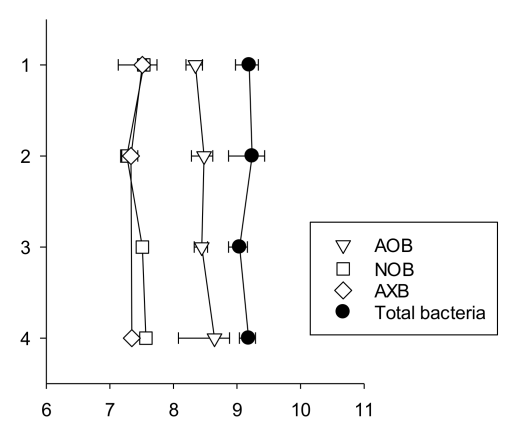

Log Abundance (cells g-LESA ${ }^{-1}$ )

Figure 2. Representative graphs showing the vertical profiles of abundance for total bacteria, ammonium oxidizing bacteria (AOB), nitrite oxidizing bacteria (NOB), and anammox bacteria (AXB) in each reactor. The top row $(\mathbf{a}, \mathbf{b})$ presents data from the end of the 24 cycles day $^{-1}$ treatment, and the bottom row $(\mathbf{c}, \mathbf{d})$ is from the treatment with 4 cycles day $^{-1}$. Points represent means with standard error bars $(\mathrm{N}=3$ replicate samples per reactor per sampling depth). Whenever ANOVA revealed an effect of depth (Table 1), Tukey's post hoc tests were used for pairwise comparisons; within a given functional group, means with the same lower-case letter are not significantly different.

Table 1. Results ( $p$-values) for ANOVA applied to compare the abundance of each microbial group across the sampling depths for the graphs presented in Figure 2. AOB: ammonium oxidizing bacteria, NOB: nitrite oxidizing bacteria, and AXB: anaerobic ammonium oxidizing bacteria.

\begin{tabular}{ccccc}
\hline \multirow{2}{*}{ Microbial Group } & \multicolumn{2}{c}{ 24 Cycles Day $^{\mathbf{1}}$} & \multicolumn{2}{c}{ 4 Cycles Day } \\
\cline { 2 - 5 } & High N & Low N & High N & Low N \\
\hline Total bacteria & $<0.001^{*}$ & 0.57 & 0.37 & 0.96 \\
AOB & $0.001^{*}$ & $<0.001^{*}$ & 0.34 & 0.94 \\
NOB & $0.003^{*}$ & $0.004^{*}$ & 0.34 & 0.90 \\
AXB & $0.60^{*}$ & 0.94 & 0.49 & 0.53
\end{tabular}

Note: ${ }^{*} p<0.05$ indicates significant differences across the four sampling depths.

The total abundance of each bacterial group in each reactor was calculated and compared across cycling regimes and $\mathrm{N}$ loadings. Abundance was consistently greater in the High-N reactor, usually by a factor of at least 3, than the corresponding abundance value in the Low-N reactor (Figure 3). For the 
High-N reactor, faster cycling rates (e.g., 24) tended to support a greater overall abundance of bacteria and a greater abundance of AOB (Figure 3a). The relative abundance of NOB did not change much with cycling rate, but there appears to be a modest increase in AXB with less frequent cycling. For the Low-N reactor (Figure $3 b$ ), no consistent trends were observed across cycling treatments.

Considering all treatments, $\mathrm{N}$ loads, and sampling depths (Figure 4), we see a strong correlation between total bacterial abundance and the abundance of both $\mathrm{AOB}(r=0.71)$ and NOB $(r=0.59)$. Furthermore, AOB and NOB abundance are strongly correlated $(r=0.72)$. In contrast, AXB abundance was not correlated with any of the other microbial data (Figure $4 \mathrm{~d}-\mathrm{f}$ ).

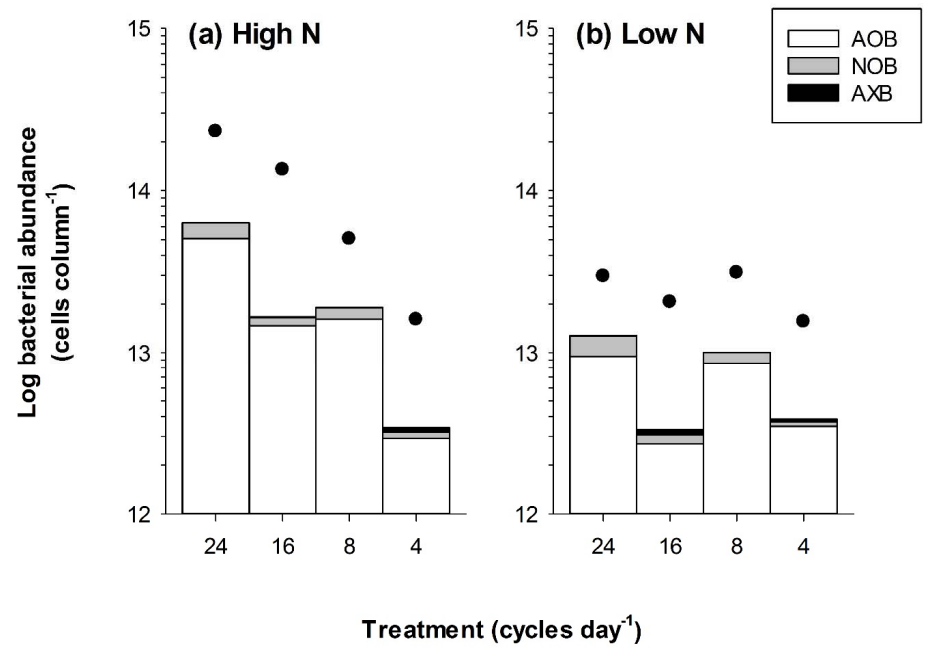

Figure 3. Integrated bacterial abundance for the (a) High-N and (b) Low-N reactors for each cycling frequency. Functional groups are presented in the bar graph as ammonium oxidizing bacteria (AOB), nitrite oxidizing bacteria (NOB), and anammox bacteria (AXB); total bacteria abundance is shown with the black circles.
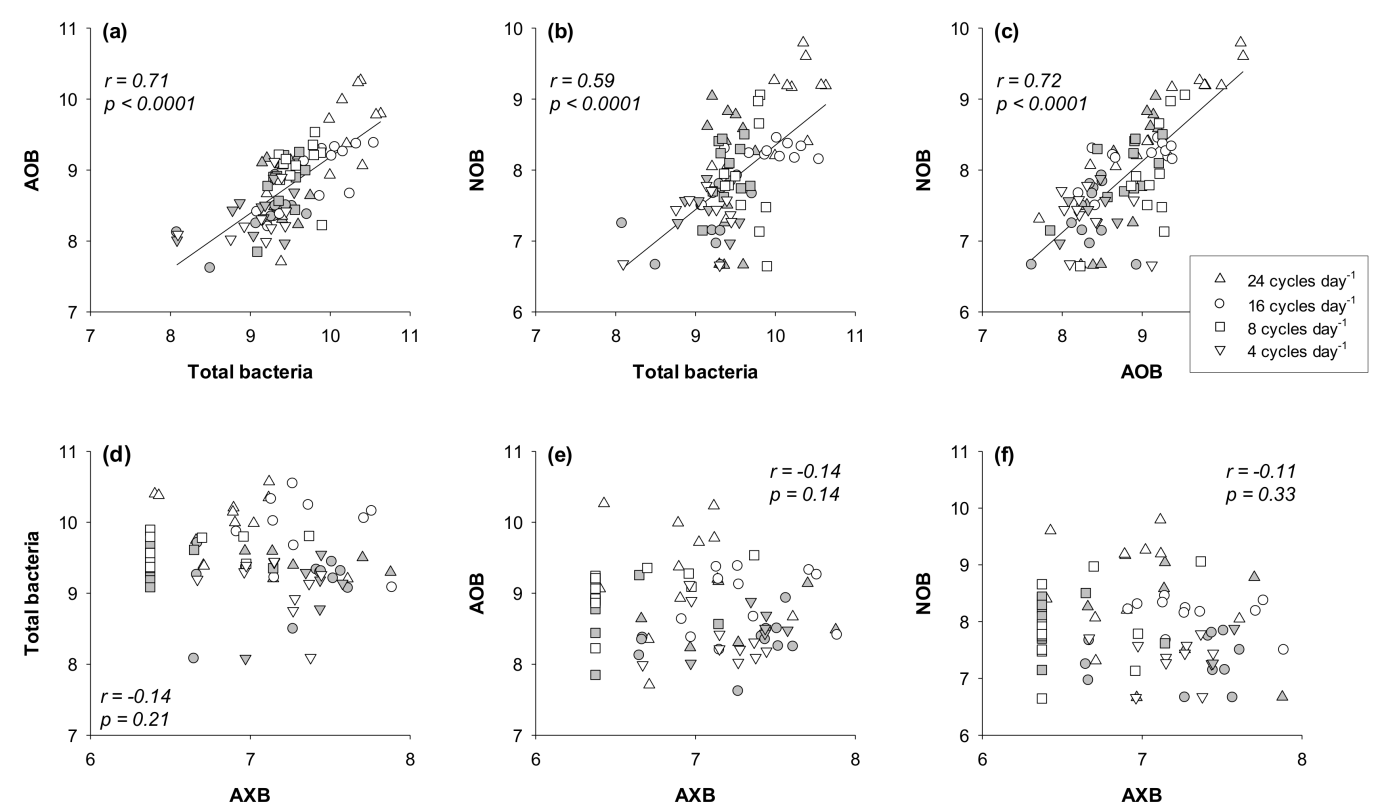

Figure 4. Pairwise comparisons of the log abundance of total bacteria, ammonium oxidizing bacteria $(\mathrm{AOB})$, nitrite oxidizing bacteria (NOB), and anammox bacteria (AXB) for each sample analyzed in this study. The $r$ values are Pearson correlation coefficients. Symbol shapes indicate the cycling treatment, open symbols represent the High-N reactor, and shaded symbols represent the Low-N system. 


\subsection{Water Chemistry}

The concentration of $\mathrm{NH}_{4}{ }^{+}, \mathrm{NO}_{3}{ }^{-}$, and total $\mathrm{N}$ changed depending on cycling rate and $\mathrm{N}$ loading (Figure 5). In the fluid associated with the High-N treatment (Figure 5a), $\mathrm{NH}_{4}{ }^{+}$concentrations were lowest during the 24 (mean \pm S.E. of the four weekly samples collected during the " 24 cycles per day" period: $44.6 \pm 4.7 \mathrm{mg} \mathrm{NH}_{4}{ }^{+}-\mathrm{N} \mathrm{L}^{-1}$ ) and 16 cycles day $^{-1}$ (38.8 \pm 21.9$)$ treatments, and considerably higher when the cycling rate was decreased to 8 (124.4 \pm 70.2$)$ and 4 times per day $(220.8 \pm 18.2)$. The concentration of $\mathrm{NO}_{3}{ }^{-}$in the High- $\mathrm{N}$ treatment varied more widely, but, like $\mathrm{NH}_{4}{ }^{+}$, changed based on cycling frequency. Specifically, values were lower during the 8- $\left(41.9 \pm 21.9 \mathrm{mg} \mathrm{NO}_{3}{ }^{-}-\mathrm{N} \mathrm{L}^{-1}\right)$ and 4 cycles day $^{-1}(10.8 \pm 2.2)$ treatments compared to faster cycling rates $(24: 438.7 \pm 28.9 ; 16: 439.1 \pm 86.3)$. The weekly chemical data were consistent with the observed changes in abundance of the functional groups. For example, when $\mathrm{AOB}$ was most abundant (24 cycles), $\mathrm{NH}_{4}{ }^{+}$concentrations were at their lowest.

The $\mathrm{NH}_{4}{ }^{+}$and $\mathrm{NO}_{3}{ }^{-}$concentrations associated with the Low- $\mathrm{N}$ reactor (Figure $5 \mathrm{~b}$ ) were considerably less variable than were observed in the High- $\mathrm{N}$ reactor. The average $\mathrm{NH}_{4}{ }^{+}$concentration was lowest when tidal cycling occurred $24\left(0.4 \pm 0.0 \mathrm{mg} \mathrm{NH}_{4}{ }^{+}-\mathrm{N} \mathrm{L}^{-1}\right)$ or $16(2.9 \pm 2.4)$ times per day, and increased when cycling frequency decreased (8: $11.0 \pm 6.0 ; 4: 25.7 \pm 2.3)$. Overall, $\mathrm{NO}_{3}{ }^{-}$ concentration decreased with cycling rate from a high of $342.5 \mathrm{mg} \mathrm{L}^{-1} \mathrm{NO}_{3}{ }^{-}-\mathrm{N}$ in the 24 cycles day ${ }^{-1}$ treatment down to $76.6 \mathrm{mg} \mathrm{L}^{-1}$ when the columns cycled only 4 times per day.

(a) High $\mathrm{N}$

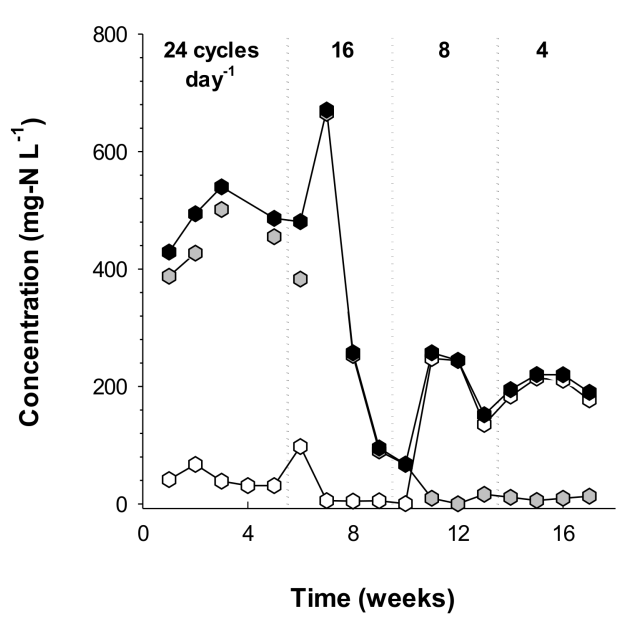

(b) Low $\mathrm{N}$

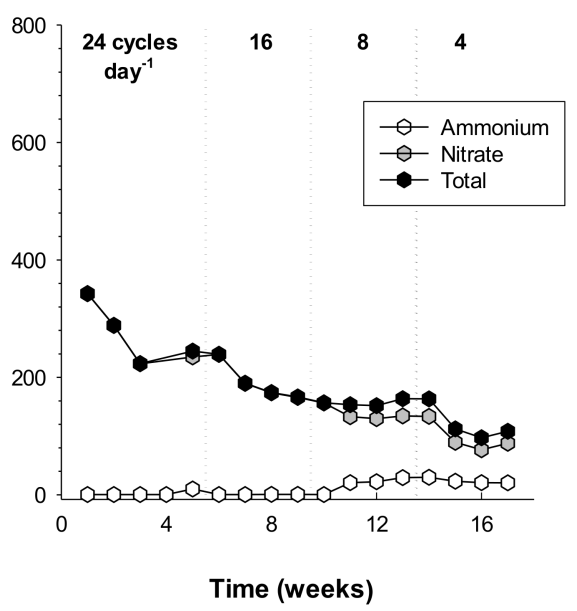

Figure 5. Concentration of ammonium $\left(\mathrm{NH}_{4}{ }^{+}\right)$, nitrate $\left(\mathrm{NO}_{3}{ }^{-}\right)$, and total inorganic $\mathrm{N}$ in the reservoir fluid associated with the High-N (a) and Low-N (b) reactors. Vertical dashed lines separate each cycling treatment. The $x$-axis presents time (in weeks) since the start of the experimental manipulations (i.e., after the six-month equilibration phase).

\subsection{Nitrogen Removal Efficiency}

At the end of each week, the total $\mathrm{N}$ remaining in each reactor system was calculated as the sum of the $\mathrm{NO}_{3}{ }^{-}$and $\mathrm{NH}_{4}{ }^{+}$concentrations multiplied by the volume of wastewater (as mentioned above, $\mathrm{NO}_{2}{ }^{-}$concentrations were always $<0.1 \mathrm{mg} \mathrm{L}^{-1}$ and thus were not included in this mass balance). This calculated mass of $\mathrm{N}$ was subtracted from the total available $\mathrm{N}$ (residual $\mathrm{N}$ from the prior sampling + total $\mathrm{N}$ from daily additions) to estimate the $\mathrm{N}$ loss per week. This value was divided by the total $\mathrm{N}$ added for the week to generate $\mathrm{N}$-removal efficiency represented as a percentage. Over the duration of the study, the High- $\mathrm{N}$ reactor averaged $85 \% \mathrm{~N}$ removal, while the Low- $\mathrm{N}$ system averaged $71 \%$ removal (Table 2). Efficiency varied somewhat, depending on cycling regime, but was always higher in the High- $\mathrm{N}$ treatment. These calculations assume that the amount of $\mathrm{N}$ stored in microbial biomass does not change over the sampling period, which is reasonable given the relatively 
small changes in bacterial abundance that we observed. These calculations also assume that there is little change in the concentration of organic and precipitated $\mathrm{N}$ compounds during the experiment.

Table 2. Average and standard error for $\mathrm{N}$ removal efficiency (\%) in the High- and Low-N columns during each cycling treatment.

\begin{tabular}{ccc}
\hline \multirow{2}{*}{ Treatment $_{\left(\text {Cycles Day }^{-1} \text { ) }\right.}$} & \multicolumn{2}{c}{ Nitrogen Loading } \\
\cline { 2 - 3 } & High N & Low N \\
\hline 24 & $79.3 \pm 3.4$ & $63.3 \pm 4.5$ \\
16 & $84.9 \pm 8.0$ & $70.0 \pm 0.5$ \\
8 & $87.4 \pm 4.0$ & $70.5 \pm 0.6$ \\
4 & $86.6 \pm 1.3$ & $80.3 \pm 1.5$ \\
\hline
\end{tabular}

\section{Discussion}

In the reactors, $\mathrm{AOB}, \mathrm{NOB}$, and $\mathrm{AXB}$ were detected at all depths and all inundation frequencies (Figures 2 and 3). The abundance data demonstrate that nitrifiers were the dominant group of $\mathrm{N}$-oxidizing bacteria in the community; $\mathrm{AOB}$ and NOB collectively were $\sim 30 \%$ of the total bacterial abundance while AXB was always less than $2 \%$. Microbial communities so highly dominated by nitrifiers are common in well-oxygenated wastewater systems with little or no organic matter [32-34]. However, their persistence in our reactors, which had a much higher organic load, was a bit surprising. Specifically, heterotrophic activity associated with this high organic load was expected to consume most, if not all, of the $\mathrm{O}_{2}$ in the reactor during flooded periods of the low cycling frequency, leaving little to support the aerobic nitrifiers. The persistence of an active community of nitrifiers, even when the cycling frequency was decreased to four (i.e., $3 \mathrm{~h}$ periods of flooding), suggests that $\mathrm{O}_{2}$ never became a limiting resource in these systems and/or that the reactor selected for a group of nitrifiers that are robust and able to survive periods of low-oxygen stress. The latter is consistent with the recent work that documents certain species of nitrifiers thrive in low-oxygen conditions (e.g., see Geets et al. [35]) and when presented with alternating anoxic/aerobic conditions [36]. Our results are also consistent with the work of $\mathrm{Wu}$ et al. [37], who found enhanced nitrification capacity (i.e., higher rates of $\mathrm{NH}_{4}{ }^{+}$removal and $\mathrm{NO}_{3}{ }^{-}$production) despite high organic loads (up to $\mathrm{BOD}_{5} \sim 200 \mathrm{mg} \mathrm{L}^{-1}$ ).

The presence of an active population of $\mathrm{NOB}$, consuming all the available $\mathrm{NO}_{2}{ }^{-}$, is one likely factor that contributed to low $\mathrm{AXB}$ abundance. Other researchers have found that the growth of $\mathrm{AXB}$ can be encouraged in single-stage reactors by operating under more oxygen-limited conditions. Because AOB have a higher $\mathrm{O}_{2}$ affinity than $\mathrm{NOB}$, they outcompete the NOB for the limited $\mathrm{O}_{2}$ during aerobic phases, which leads to an accumulation of $\mathrm{NO}_{2}{ }^{-}$that is available for AXB during anaerobic phases [38,39]. Interestingly, high levels of $\mathrm{NO}_{2}{ }^{-}$are inhibitory to anammox (e.g., [40-43]), so the balance between the different microbial groups is very important [44]. In our reactors, the low abundance of $\mathrm{AXB}$ and lack of $\mathrm{NO}_{2}{ }^{-}$accumulation are further support that $\mathrm{O}_{2}$ was not a major common limiting factor in these reactors.

In this study, AXB made up a very small fraction of the total bacterial community $(<2 \%)$, and abundance did not change consistently due to $\mathrm{N}$ loading (Figures 2 and 3), cycling rate (Figure 3), or abundance of other microbial groups (Figure 4). Given the overall low abundance of AXB, and the fact that these organisms are notoriously slow growing [45], their potential contribution to $\mathrm{N}$ removal in this system appears to be limited. Using the maximum specific anammox activity rate reported by Daverey [46] (ca. $30 \mathrm{mg} \mathrm{N}_{2}-\mathrm{N}$ produced per gram of cells per day), the amount of $\mathrm{N}$ removed from the columns in this study each day by anammox would only be $\sim 0.5 \%$ of the daily addition. The low abundance of AXB in these columns could be due to several factors including availability of organic matter, $\mathrm{O}_{2}, \mathrm{NH}_{4}{ }^{+}$, and $\mathrm{NO}_{2}{ }^{-}$. Systems that typically enrich for anammox have $\mathrm{NH}_{4}{ }^{+}$ and $\mathrm{NO}_{2}{ }^{-}$available in a stable anaerobic environment with low organic carbon (e.g., Liu et al. [47], Monballiu et al. [48], and Okamotoa et al. [49]). In contrast, the reactors used in the present study had a 
relatively high organic load and were continually subjected to perturbation including periods of low $\mathrm{O}_{2}$ stress, which is strongly inhibitory to anammox [11]. However, there have been other studies that have demonstrated that anammox can be reversibly inhibited by $\mathrm{O}_{2}$ [50], making partial nitrification and anammox possible in the same reactor [51]. More likely, the AXB in our columns were inhibited by low $\mathrm{NO}_{2}{ }^{-}$availability, as discussed above, combined with high concentrations of free $\mathrm{NH}_{3}$. There were multiple instances where the free $\mathrm{NH}_{3}$ concentration in the reactors (calculated from total $\mathrm{NH}_{4}^{+}$ concentrations and $\mathrm{pH}$ ) was above the inhibitory concentrations reported by Fernandez et al. [52] and Lackner et al. [44].

In addition to considering the effect of cycling rate on microbial abundance, we also examined the effect of sampling location within the column reactor (Figure 1). We anticipated that the microbial community closer to the surface of the column (e.g., port 1) would experience more aerobic conditions due to increased $\mathrm{O}_{2}$ diffusion at the air-water interface. Furthermore, because the LESA matrix material has a high cation sorption capacity, we expected that $\mathrm{NH}_{4}{ }^{+}$availability would be greatest near the inflow point (port 4) and decrease with distance up the column. At the lower cycling rates $(16,8$, and 4 per day), we found no differences in abundance between any of the sampling ports (Figure 2c,d, Table 1), which suggest that these potential depth/location effects were minimal. At the fastest cycling rate (24 per day), we found a modest but significant increase in AOB and NOB abundance at the base of the reactor (Figure 2a,b). Interestingly, we saw no difference in bulk $\mathrm{NH}_{4}{ }^{+}$concentration between water collected at these sampling ports and the main reactor reservoir (data not presented), which suggests that microbial responses were due to locally increased $\mathrm{NH}_{4}{ }^{+}$availability near the LESA surface. This observation is consistent with prior research that shows electrostatic interactions associated with matrix fill material can influence $\mathrm{N}$ availability $[18,53]$. The impact of cation exchange capacity has also been documented in soil systems by Yan et al. [54]

Given the low abundance of $\mathrm{AXB}$, the high abundance of $\mathrm{AOB}$ and NOB, and the amount of $\mathrm{NO}_{3}{ }^{-}$present during the high-frequency cycling, nitrification was clearly the dominant oxidative process in the columns. Furthermore, the disappearance of the $\mathrm{NO}_{3}{ }^{-}$when the inundation duration was lengthened suggests that N-removal in these reactors was accomplished by coupled nitrification/denitrification. In the Low-N reactor, nitrification seemed to be less affected by cycling rate compared to the High-N reactor. For example, even when cycling frequency was lowered to only four times per day, the increase in $\mathrm{NH}_{4}{ }^{+}$concentration in the Low-N reactor was modest (Figure 5b) compared to the corresponding change for the High-N reactor (Figure 5a). This could be due to the low $\mathrm{N}$ reactor enriching for a nitrifying population adapted to $\mathrm{O}_{2}$ stress as well as limited $\mathrm{N}$ availability [36,55]. It is also possible that the difference in $\mathrm{N}$ load affected the balance of AOA to AOB, as several recent studies have suggested that $\mathrm{NH}_{4}{ }^{+}$availability influences niche separation of these two groups (see references in Geets et al. [35]). AOA are thought to predominate in more oligotrophic conditions and, for this reason, their abundance in wastewater systems is generally low. For example, Bai et al. [8] surveyed six wastewater treatment systems and found the abundance of AOA to be less than $1 \%$ of the AOB abundance. Similarly, Park et al. [56] surveyed nine geographically distributed wastewater treatment plants in which nitrification was active and found molecular evidence of AOA at only five of the plants. However, both of these studies focused on wastewater treatment plants with relatively high $\mathrm{NH}_{4}{ }^{+}$concentrations. More recent work by Sauder et al. [57] considered a gradient of wastewater $\mathrm{NH}_{4}{ }^{+}$concentrations and found that $\mathrm{AOA}$ represented a substantial proportion of the ammonium-oxidizing community in low(er)- $\mathrm{NH}_{4}{ }^{+}$wastewater. Furthermore, their findings suggest that some lineages of AOA are adapted to environments with varying nutrient status. Additional study of $\mathrm{AOA}$ and $\mathrm{AOB}$ community composition in these reactors could provide insight into the response of tidal treatment systems to varying $\mathrm{N}$ loads and environmental perturbations.

Though rare, AXB were ubiquitous in both reactors, and their persistence despite frequent perturbations, including periods of $\mathrm{O}_{2}$ inhibition and potential $\mathrm{NH}_{4}{ }^{+}$toxicity, suggests they may be a more robust group of organisms than previously assumed. These results also suggest that it may be possible to adjust operating conditions in fill-and-drain systems to facilitate higher abundance of 
$\mathrm{AXB}$ and, perhaps, significant levels of $\mathrm{N}$ removal via anammox. From an ecological perspective, this research highlights the need to consider complex multi-dimensional resource gradients in order to understand the survival and function of potentially competing populations. The patterns manifested in this study represent an integrated response of the various microbial populations to the availability of $\mathrm{NH}_{4}{ }^{+}$, free $\mathrm{NH}_{3}, \mathrm{NO}_{2}{ }^{-}, \mathrm{NO}_{3}{ }^{-}$, and $\mathrm{O}_{2}$, each of which can serve as a key resource to one population while being inhibitory to others or at other concentrations. The reactor design promoted temporal niche partitioning (i.e., wet and dry phases) over the development of spatial gradients (i.e., patterns with depth).

The $\mathrm{N}$ removal efficiency achieved in our reactors represents an improvement over prior studies. For example, Chan et al. [58] only achieved a removal rate of 50\%, operating with a contact time of 18 hours. Like us, Cui et al. [59] found that efficiency varied depending on hydraulic loading rate, but their $\mathrm{NH}_{4}{ }^{+}$removal was never more than $\sim 72 \%$. Hu et al. [60] explored a "multi-tide" system and achieved $\sim 85 \% \mathrm{~N}$ removal in a system with three cycles per day. Interestingly, Hu et al. [60] concluded that "bed rest time" (i.e., the length of the aerobic phase) was key because that time interval determined the extent to which the adsorption capacity of the matrix could be "regeneration by nitrification." This finding is consistent with our results in the Low-N reactor, but changing the duration of the aerobic phase has less of an effect when the $\mathrm{N}$ load was higher. Total $\mathrm{N}$ removal in our columns appeared to be limited by the duration of the anaerobic phase, given that we were always able to detect residual $\mathrm{NO}_{3}{ }^{-}$in the wastewater reservoir.

\section{Conclusions}

This study supports the growing body of evidence that tidal-flow systems are an efficient means of $\mathrm{N}$ removal, and that nitrification and denitrification can be carried out in a single reactor chamber by staging aerobic and anaerobic conditions through sequential filling and draining, respectively. In this study, we achieved higher $\mathrm{N}$ removal efficiency than prior systems and gained important novel information about the effects of tidal cycling rate. Our best results were observed at a cycling rate of 4 day $^{-1}$. This study is one of the first to attempt to disentangle the factors that control the abundance and distribution of $\mathrm{N}$ oxidation bacteria. Given that $\mathrm{N}$ oxidation is the first and rate-limiting step associated with microbial $\mathrm{N}$ removal of these reactors, a better understanding of these populations is key to enhancing performance. Although anammox-capable organisms were present in these reactors, their numbers were so low that their quantitative contribution to removal of $\mathrm{N}$ was negligible compared to coupled nitrification-denitrification reactions. Systems of this general design may find application for point-of-use treatment of wastewater, especially to levels suitable for secondary uses such as chiller water, toilet flushing, or irrigation.

Acknowledgments: Joseph M. Battistelli received partial support for this work from the Virginia Space Grant Consortium and a NASA Graduate Student Research Program Fellowship. The authors thank Bonnie Brown, who was of great help in developing the FISH protocols, as well as Kristina Reid Black, Rachel Turley and Eric Lohan for their assistance in monitoring the reactors and processing samples. The authors also thank Chansotheary Dang for help with microscopy.

Author Contributions: Joseph M. Battistelli and Aaron L. Mills conceived of and designed the experiment. Joseph M. Battistelli collected samples and performed FISH and subsequent microscopic analysis. Rima B. Franklin and Aaron L. Mills provided reagents and materials for sample collection and analysis, as well as equipment access. Joseph M. Battistelli, Rima B. Franklin, and Aaron L. Mills analyzed the data and wrote the paper.

Conflicts of Interest: The authors declare no conflict of interest.

\section{References}

1. Gleick, P.H. Water use. Annu. Rev. Environ. Resour. 2003, 28, 275-314. [CrossRef]

2. Galloway, J.N.; Cowling, E.B. Reactive nitrogen and the world: 200 years of change. Ambio 2002, 31, 64-71. [CrossRef] [PubMed] 
3. Vitousek, P.M.; Aber, J.D.; Howarth, R.W.; Likens, G.E.; Matson, P.A.; Schindler, D.W.; Schlesinger, W.H.; Tilman, D. Human alteration of the global nitrogen cycle: Sources and consequences. Ecol. Appl. 1997, 7, 737-750. [CrossRef]

4. Zhu, G.; Peng, Y.; Li, B.; Guo, J.; Yang, Q.; Wang, S. Biological removal of nitrogen from wastewater. In Reviews of Environmental Contamination and Toxicology; Whitacre, D.M., Ed.; Springer: New York, NY, USA, 2008; pp. 159-195.

5. United States Environmental Protection Agency (EPA). Manual for Nitrogen Control; EPAl625/R-; USEPA: Washington, DC, USA, 1993.

6. United States Environmental Protection Agency (EPA). Toxicity Reduction Evaluation Guidance for Municipal Wastewater Treatment Plants; USEPA: Washington, DC, USA, 1999.

7. Hatzenpichler, R. Diversity, physiology, and niche differentiation of ammonia-oxidizing archaea. Appl. Environ. Microbiol. 2012, 78, 7501-7510. [CrossRef] [PubMed]

8. Bai, Y.; Sun, Q.; Wen, D.; Tang, X. Abundance of ammonia-oxidizing bacteria and archaea in industrial and domestic wastewater treatment systems. FEMS Microbiol. Ecol. 2012, 80, 323-330. [CrossRef] [PubMed]

9. Jetten, M.S.M.; Wagner, M.; Fuerst, J.; van Loosdrecht, M.; Kuenen, G.; Strous, M. Microbiology and application of the anaerobic ammonium oxidation ('anammox') process. Curr. Opin. Biotechnol. 2001, 12, 283-288. [CrossRef]

10. Tsushima, I.; Ogasawara, Y.; Kindaichi, T.; Satoh, H.; Okabe, S. Development of high-rate anaerobic ammonium-oxidizing (anammox) biofilm reactors. Water Res. 2007, 41, 1623-1634. [CrossRef] [PubMed]

11. Van de Graaf, A.A.; Mulder, A.; Debruijn, P.; Jetten, M.S.M.; Robertson, L.A.; Kuenen, J.G. Anaerobic oxidation of ammonium is a biologically mediated process. Appl. Environ. Microbiol. 1995, 61, 1246-1251. [PubMed]

12. Brix, H. Gas-exchange through the soil atmosphere interphase and through dead culms of Phragmites australis in a constructed reed bed receiving domestic sewage. Water Res. 1990, 24, 259-266. [CrossRef]

13. Luederitz, V.; Eckert, E.; Lange-Weber, M.; Lange, A.; Gersberg, R.M. Nutrient removal efficiency and resource economics of vertical flow and horizontal flow constructed wetlands. Ecol. Eng. 2001, 18, 157-171. [CrossRef]

14. Pan, J.; Zhang, H.; Li, W.; Ke, F. Full-scale experiment on domestic wastewater treatment by combining artificial aeration vertical- and horizontal-flow constructed wetlands system. Water Air Soil Pollut. 2012, 223, 5673-5683. [CrossRef]

15. Tuncsiper, B. Nitrogen removal in a combined vertical and horizontal subsurface-flow constructed wetland system. Desalination 2009, 247, 466-475. [CrossRef]

16. Austin, D.; Nivala, J. Energy requirements for nitrification and biological nitrogen removal in engineered wetlands. Ecol. Eng. 2009, 35, 184-192. [CrossRef]

17. Sun, G.; Gray, K.R.; Biddlestone, A.J.; Cooper, D.J. Treatment of agricultural wastewater in a combined tidal flow-downflow reed bed system. Water Sci. Technol. 1999, 40, 139-146.

18. Austin, D. Influence of cation exchange capacity (CEC) in a tidal flow, flood and drain wastewater treatment wetland. Ecol. Eng. 2006, 28, 35-43. [CrossRef]

19. Austin, D.; Lohan, E.; Verson, E. Nitrification and denitrification in a tidal vertical flow wetland plot. In Proceedings of the Water Environment Technical Conference; Water Environment Federation: Los Angeles, CA, USA, 2003.

20. United States Environmental Protection Agency (EPA). Method 9081-Cation Exchange Capacity of Soils; EPA: Washington, DC, USA, 1986.

21. Tokunaga, T.K.; Olson, K.R.; Wan, J. Moisture characteristics of Hanford gravels: Bulk, grain-surface, and intragranular components. Vadose Zone J. 2003, 2, 322-329. [CrossRef]

22. Abou-Elela, S.I.; Hellal, M.S. Municipal wastewater treatment using vertical flow constructed wetlands planted with Canna, Phragmites and Cyprus. Ecol. Eng. 2012, 47, 209-213. [CrossRef]

23. Boursier, H.; Beline, F.; Paul, E. Piggery wastewater characterisation for biological nitrogen removal process design. Bioresour. Technol. 2005, 96, 351-358. [CrossRef] [PubMed]

24. Battistelli, J.M. Distribution of Nitrifying Bacteria under Fluctuating Environmental Conditions. Ph.D. Dissertation, University of Virginia, Charlottesville, VA, USA, 2012. 
25. Wright, S.F. Serology and Conjugation of Antibodies. In Methods of Soil Analysis: Part 2-Microbiological and Biochemical Properties; SSSA Book Series SV-5.2; Soil Science Society of America: Madison, WI, USA, 1994; pp. 593-618.

26. Higgins, C. The Potential for Eutrophication Mitigation from Aquaculture of the Native Oyster Crassostrea virginica, in Chesapeake Bay: Quantitative Assessment of an Ecosystem Service. Ph.D. Dissertation, Virginia Commonwealth University, Richmond, VA, USA, 2011.

27. Krasnits, E.; Friedler, E.; Sabbah, I.; Beliavski, M.; Tarre, S.; Green, M. Spatial distribution of major microbial groups in a well established constructed wetland treating municipal wastewater. Ecol. Eng. 2009, 35, 1085-1089. [CrossRef]

28. Woznica, A.; Nowak, A.; Beimfohr, C.; Karczewski, J.; Bernas, T. Monitoring structure and activity of nitrifying bacterial biofilm in an automatic biodetector of water toxicity. Chemosphere 2010, 78, 1121-1128. [CrossRef] [PubMed]

29. Schmid, M.; Walsh, K.; Webb, R.; Rijpstra, W.I.C.; van de Pas-Schoonen, K.; Verbruggen, M.J.; Hill, T.; Moffett, B.; Fuerst, J.; Schouten, S.; et al. Candidatus "Scalindua brodae", sp. nov., Candidatus "Scalindua wagneri", sp. nov., two new species of anaerobic ammonium oxidizing bacteria. Syst. Appl. Microbiol. 2003, 26, 529-538. [CrossRef] [PubMed]

30. Neef, A.; Amann, R.; Schlesner, H.; Schleifer, K.H. Monitoring a widespread bacterial group: In situ detection of planctomycetes with $16 S$ rRNA-targeted probes. Microbiology 1998, 144, 3257-3266. [CrossRef] [PubMed]

31. Brandsma, J.; van de Vossenberg, J.; Risgaard-Petersen, N.; Schmid, M.C.; Engstrom, P.; Eurenius, K.; Hulth, S.; Jaeschke, A.; Abbas, B.; Hopmans, E.C.; et al. A multi-proxy study of anaerobic ammonium oxidation in marine sediments of the Gullmar Fjord, Sweden. Environ. Microbiol. Rep. 2011, 3, 360-366. [CrossRef] [PubMed]

32. Hao, X.; Wang, Q.; Zhang, X.; Cao, Y.; van Mark Loosdrecht, C.M. Experimental evaluation of decrease in bacterial activity due to cell death and activity decay in activated sludge. Water Res. 2009, 43, 3604-3612. [CrossRef] [PubMed]

33. Smith, D.P.; Rector, T.; Reid-Black, K.; Hummerick, M.; Strayer, R.; Birmele, M.; Roberts, M.S.; Garland, J.L. Redox control bioreactor: A unique biological water processor. Biotechnol. Bioeng. 2008, 99, 830-845. [CrossRef] [PubMed]

34. Norton, J.M. Diversity and environmental distribution of ammonia-oxidizing bacteria. In Nitrification; Ward, B.B., Arp, D.J., Klotz, M.G., Eds.; ASM Press: Washington, DC, USA, 2011; pp. 39-56. ISBN 9781843395461.

35. Geets, J.; Boon, N.; Verstraete, W. Strategies of aerobic ammonia-oxidizing bacteria for coping with nutrient and oxygen fluctuations. FEMS Microbiol. Ecol. 2006, 58, 1-13. [CrossRef] [PubMed]

36. Dytczak, M.A.; Londry, K.L.; Oleszkiewicz, J.A. Activated sludge operational regime has significant impact on the type of nitrifying community and its nitrification rates. Water Res. 2008, 42, 2320-2328. [CrossRef] [PubMed]

37. Wu, S.; Zhang, D.; Austin, D.; Dong, R.; Pang, C. Evaluation of a lab-scale tidal flow constructed wetland performance: Oxygen transfer capacity, organic matter and ammonium removal. Ecol. Eng. 2011, 37, 1789-1795. [CrossRef]

38. Blackburne, R.; Yuan, Z.; Keller, J. Partial nitrification to nitrite using low dissolved oxygen concentration as the main selection factor. Biodegradation 2008, 19, 303-312. [CrossRef] [PubMed]

39. Wyffels, S.; Van Hulle, S.W.H.; Boeckx, P.; Volcke, E.I.P.; Van Cleemput, O.; Vanrolleghem, P.A.; Verstraete, W. Modeling and simulation of oxygen-limited partial nitritation in a membrane-assisted bioreactor (MBR). Biotechnol. Bioeng. 2004, 86, 531-542. [CrossRef] [PubMed]

40. Strous, M.; Kuenen, J.G.; Jetten, M.S.M. Key physiology of anaerobic ammonium oxidation. Appl. Environ. Microbiol. 1999, 65, 3248-3250. [PubMed]

41. Dapena-Mora, A.; Fernandez, I.; Campos, J.L.; Mosquera-Corral, A.; Mendez, R.; Jetten, M.S.M. Evaluation of activity and inhibition effects on anammox process by batch tests based on the nitrogen gas production. Enzyme Microb. Technol. 2007, 40, 859-865. [CrossRef]

42. Fux, C.; Huang, D.; Monti, A.; Siegrist, H. Difficulties in maintaining long-term partial nitritation of ammonium-rich sludge digester liquids in a moving-bed biofilm reactor (MBBR). Water Sci. Technol. 2004, 49, 53-60. [PubMed]

43. Jin, R.-C.; Yang, G.-F.; Yu, J.-J.; Zheng, P. The inhibition of the anammox process: A review. Chem. Eng. J. 2012, 197, 67-79. [CrossRef] 
44. Lackner, S.; Gilbert, E.M.; Vlaeminck, S.E.; Joss, A.; Horn, H.; van Loosdrecht, M.C.M. Full-scale partial nitritation/anammox experiences-An application survey. Water Res. 2014, 55, 292-303. [CrossRef] [PubMed]

45. Tal, Y.; Watts, J.E.M.; Schreier, H.J. Anaerobic ammonium-oxidizing (anammox) bacteria and associated activity in fixed-film biofilters of a marine recirculating aquaculture system. Appl. Environ. Microbiol. 2006, 72, 2896-2904. [CrossRef] [PubMed]

46. Daverey, A.; Chei, P.C.; Dutta, K.; Lin, J.-G. Statistical analysis to evaluate the effects of temperature and $\mathrm{pH}$ on anammox activity. Int. Biodeterior. Biodegrad. 2015, 102, 89-93. [CrossRef]

47. Liu, S.T.; Horn, H.; Mueller, E. A systematic insight into a single-stage deammonification process operated in granular sludge reactor with high-loaded reject-water: Characterization and quantification of microbiological community. J. Appl. Microbiol. 2013, 114, 339-351. [CrossRef] [PubMed]

48. Monballiu, A.; Desmidt, E.; Ghyselbrecht, K.; De Clippeleir, H.; Van Hulle, S.W.H.; Verstraete, W.; Meesschaert, B. Enrichment of anaerobic ammonium oxidizing (anammox) bacteria from OLAND and conventional sludge: Features and limitations. Sep. Purif. Technol. 2013, 104, 130-137. [CrossRef]

49. Okamoto, H.; Kawamura, K.; Nishiyama, T.; Fujii, T.; Furukawa, K. Development of a fixed-bed anammox reactor with high treatment potential. Biodegradation 2013, 24, 99-110. [CrossRef] [PubMed]

50. Strous, M.; VanGerven, E.; Zheng, P.; Kuenen, J.G.; Jetten, M.S.M. Ammonium removal from concentrated waste streams with the anaerobic ammonium oxidation (anammox) process in different reactor configurations. Water Res. 1997, 31, 1955-1962. [CrossRef]

51. Third, K.A.; Paxman, J.; Schmid, M.; Strous, M.; Jetten, M.S.M.; Cord-Ruwisch, R. Enrichment of anammox from activated sludge and its application in the CANON process. Microb. Ecol. 2005, 49, 236-244. [CrossRef] [PubMed]

52. Fernandez, I.; Dosta, J.; Fajardo, C.; Campos, J.L.; Mosquera-Corral, A.; Mendez, R. Short- and long-term effects of ammonium and nitrite on the anammox process. J. Environ. Manag. 2012, 95, S170-S174. [CrossRef] [PubMed]

53. Gisvold, B.; Ødegaard, H.; Füllesdal, M. Enhanced removal of ammonium by combined nitrification/ adsorption in expanded clay aggregate filters. Water Sci. Technol. 2000, 41, 409-416.

54. Yan, A.; Liu, C.; Liu, Y.; Xu, F. Effect of ion exchange on the rate of aerobic microbial oxidation of ammonium in hyporheic zone sediments. Environ. Sci. Pollut. Res. 2018, 25, 8880-8887. [CrossRef] [PubMed]

55. Bellucci, M.; Ofiţeru, I.D.; Graham, D.W.; Head, I.M.; Curtis, T.P. Low-dissolved-oxygen nitrifying systems exploit ammonia-oxidizing bacteria with unusually high yields. Appl. Environ. Microbiol. 2011, 77, 7787-7796. [CrossRef] [PubMed]

56. Park, H.-D.; Wells, G.F.; Bae, H.; Criddle, C.S.; Francis, C.A. Occurrence of ammonia-oxidizing archaea in wastewater treatment plant bioreactors. Appl. Environ. Microbiol. 2006, 72, 5643-5647. [CrossRef] [PubMed]

57. Sauder, L.A.; Peterse, F.; Schouten, S.; Neufeld, J.D. Low-ammonia niche of ammonia-oxidizing archaea in rotating biological contactors of a municipal wastewater treatment plant. Environ. Microbiol. 2012, 14, 2589-2600. [CrossRef] [PubMed]

58. Chan, S.Y.; Tsang, Y.F.; Chua, H.; Sin, S.N.; Cui, L.H. Performance study of vegetated sequencing batch coal slag bed treating domestic wastewater in suburban area. Bioresour. Technol. 2008, 99, 3774-3781. [CrossRef] [PubMed]

59. Cui, L.; Feng, J.; Ouyang, Y.; Deng, P. Removal of nutrients from septic effluent with re-circulated hybrid tidal flow constructed wetland. Ecol. Eng. 2012, 46, 112-115. [CrossRef]

60. Hu, Y.; Zhao, Y.; Rymszewicz, A. Robust biological nitrogen removal by creating multiple tides in a single bed tidal flow constructed wetland. Sci. Total Environ. 2014, 470, 1197-1204. [CrossRef] [PubMed]

(C) 2018 by the authors. Licensee MDPI, Basel, Switzerland. This article is an open access article distributed under the terms and conditions of the Creative Commons Attribution (CC BY) license (http:/ / creativecommons.org/licenses/by/4.0/). 